\title{
CLASSROOM SIMULATION METHOD INCREASES NURSING STUDENT FAMILY-FOCUSED CARE COMPETENCIES IN FAMILY NURSING LEARNING PRACTICE
}

\author{
(Metode Pembelajaran Simulasi Dalam Praktik Keperawatan Keluarga Meningkatkan \\ Kompetensi Mahasiswa Dalam Perawatan Berfokus Keluarga)
}

\author{
Stefanus Mendes Kiik*, Mahathir ${ }^{* *}$, Juli Dwi Prasetyono ${ }^{* * *}$ \\ *STIKES Maranatha Kupang, \\ Jl.Kampung Bajawa Nasipanaf, Baumata Barat Kab. Kupang, East Nusa Tenggara. \\ ${ }^{* *}$ Universitas Andalas Padang \\ ${ }^{* * *}$ STIKES Banyuwangi East Java

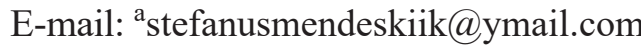

\begin{abstract}
ABSTRAK
Pendahuluan: Keperawatan merupakan keilmuan profesional yang memerlukan pendidikan formal dan pengalaman pembelajaran institusi dalam memperoleh keahlian spesifik yang dibutuhkan. Pembelajaran keperawatan keluarga merupakan salah satu pendidikan keilmuan inti keperawatan yang menuntut pendekatan khusus guna membangun hubungan profesional perawat dengan keluarga. Pendidikan perawatan berfokus keluarga menuntut pemahaman yang lebih luas dalam memperlakukan keluarga sebagai unit sistem oleh mahasiswa guna memenuhi kebutuhannya. Pendidik harus memilih metode pembelajaran efektif dan kreatif dalam mengajarkan komponen penting perawatan keluarga. Simulasi di ruang kelas merupakan metode yang dianggap mampu mengakomodir fokus pengajaran dalam pencapaian kognitif, psikomotor, caring dan proses keperawatan. Penelitian ini bertujuan mengetahui pengaruh metode pembelajaran simulasi di ruang kelas terhadap kompetensi mahasiswa dalam perawatan berfokus keluarga dengan menggunakan penilaian kompetensi perawatan berfokus keluarga rubrik Van Gelderen. Metode: Penelitian ini dilakukan dengan quasi experiment pre and post with control group design. Sampel diambil dengan teknik simple random sampling. Hasil: Penelitian telah dilakukan terhadap 34 orang yang menunjukan nilai rerata setelah perlakuan berbeda secara signifikan antara kelompok perlakuan dan kontrol melalui Mann Whitney test $(\mathrm{p}=0,000)$. Diskusi: Diperlukan penerapan metode pembelajaran simulasi di ruang kelas sebelum mahasiswa melakukan praktik keperawatan langsung ke keluarga. Penggunaan rubrik Van Gelderen sebagai instrumen mampu menilai kompetensi perawatan berfokus keluarga.
\end{abstract}

Kata kunci : Simulasi, perawatan berfokus keluarga, Rubrik Van Gelderen

\begin{abstract}
Introduction: Nursing is a professional field that requires formal education and institutional learning experiences in acquiring specific expertise. Family nursing is one of the core science in nursing education that requires a specific approach in order to build a professional nurse-family relationship. Family-focused care education demands a broader understanding in providing care for the family as a unit system by the students to meet the family needs. Educators should choose effective and creative learning methods in teaching the important component of family-focused care. Classroom simulations is a method that considered to be able to accommodate the achievement of cognitive, psychomotor, caring and nursing process. This study was conducted to identify the effectiveness of classroom simulation learning methods to student family-focused care competencies using family-focused care competency assessment by Van Gelderen rubric. Methode: This research was conducted by quasi-experimental pre and post with control group design. The sample size is done by hypothesis test two pairs population (numeric data) formula. Result: The study was conducted on 34 respondent as a sample that showed significant increasing the mean value after classroom simulation Man Whitney test $(p=0.000)$. Discussion: It is suggested the application of classroom simulation learning methods before the students perform nursing practice directly to the family. Van Gelderen rubric is an instrument which is able to assess the competence of familyfocused care.
\end{abstract}

Keywords : Simulation, classroom simulation, nursing education, family nursing, family-focused care.

\section{INTRODUCTION}

Simulation has been recognized and used in the family nursing field. Simulation is considered able to accommodate the focus of instruction in achieving psychomotor abilities, caring and nursing process in the family itself 
(Oermann and Gaberson (2014). Simulation provides an appropriate learning environment in which students will gain experience of learning directly, and it may affect the ability of the student delivering family care. The simulation also provides the opportunity for students to be able to enter into the family as a whole with a full understanding of nursing scientific knowledge thoroughly nursing practice, criticize and identify weaknesses of the students. The simulation also provides a systematic approach that can build core competencies needed in the care of the family.

Zavertnik, Huff, and Munro (2012) states that educators through simulation can provide exploration experiences on family issues. Educators provide significant activities during the process of family care. Through simulation, educators can productively to teach realistic situation and activities that will increase student competence in clinical practice in the family. Simulation gives students the opportunity to explore the emotional circumstances during interaction with the family. By entering the kind of reality situation, it directly will bring a feeling of anxiety, challenges, and distress during interaction with family. It will provide new experiences for students to find effective coping towards learning and positive change during the process of family care. Simulation in the family provides a broader reflection for students that led to the positive aspects of themselves and put aside negative values possessed.

Denham (2016), suggests that the process of education and family nursing research is still considered insufficient. This is due to the lack of scientific core integration into the family focused nursing education, and education focus is still on the mechanisms of biomedical and communications. Meanwhile, family care requires a different pedagogical approach to teach the core science in family nursing. Nursing education efforts should mind the appropriate domains that essential in family-focused care that have to be fulfilled for the students. Family-focused care actions will lead to a broader understanding and regard the family as a unit system in the fulfillment of their needs.

Van Gelderen, Krumwiede, Christian (2016), argues that the use of evaluation instruments is also an important thing in order to provide convenience in providing consistent feedback and develop skills that are essential in the family nursing for the students. Educators with clear evaluation instruments will maximize the use of learning methods by using simulations in the nursing family. Evaluation instrument that can be used is Van Galderen. Van Galderen rubric sections covering such important element factor consist of family communication and family care factors as clients. The section will provide comprehensive compliance capabilities of the student's abilities during the process of learning through simulation.

Ministry of Research and Higher Education (2014), states that the competency test is one of the indicators used to assess students' ability to perform the nursing process. In Indonesia the competency test in the field of nursing attended by 82505 participants from 416 institutions nursing Diploma.Tthe total student competency test ranges from $64.38 \%$ were successfully passed. Some of them around 40380 participants from 257 institutions only $53.61 \%$ of graduation achieved. Competency test can be used as a benchmark for institutions and educators to create strategies and better methods in teaching.

Based on the preliminary study on interviews and observations of five lecturers in 3 nursing education institutions found that the classroom simulation is not used as a learning method when the teaching-learning process of the nursing family is held. One lecturer also said that the number of credit points of family nursing is inadequate and unable to accommodate the teaching load, which is detained creative thinking space and lowering the efforts to try new teaching methods. Lecturer stated that the simulation is not so well known when teaching as the components of family nursing practice in the classroom so that the lecturer has limited options for applying the new learning method. 
Interviews were also conducted in 15 students, which states that during the learning process of family nursing in classrooms through lecture class and after that the students given the opportunity to pitch the family independently and last evaluated by the lecturers.

The application of simulation in nursing teaching families is limited, whereas simulation is a promising strategy in building and developing the ability of students in family-focused care. Simulation is usually applied in the learning practices of students, but its application in family nursing expertise is still not optimal. Not to mention, the format of assessment still not focuses on evaluating the development of the ability in family focused care measures. This study aimed to determine the effect of classroom simulation learning method in students family focused care competencies.

\section{METHODS}

The study design used in this study is quasi-experimental by pre and post with control group design. The independent variables in this study is a classroom simulation learning method. The dependent variable is the competence of students in family-focused care. The population in this study are the fourthsemester students of STIKES Maranatha Kupang. The sample in this study were 34 respondents.

The instrument used was the Van Gelderen rubric of family care- (Van Gelderen, Krumwiede \& Christian, 2016). The instrument consists of two items, which are communication-based care items and family as clients care items. Item of communications based care family consists of four elements: communication style, the use of terminology, the position of nurses and nurse eye contact while deliver of care, family as clients items consists of 7 elements : family history and methods of data collection, identifying issues and problems, the involvement of nurses, care needs follow up, showing support, hope and humor, providing family-based care approach as a client and family health habits. Each item was rated classified into positive characteristics (value 3), the characteristic needs to be improved (score 2) and characteristics that are not expected (value 1). The maximum point total is 33. Test statistics using the Mann Whitney test for unpaired data and its distribution is not normal. Data analysis using SPSS version 21 for Windows (SPSS Inc., Chicago, IL, USA). Mann Whitney test was used to compare student competence in family-focused care in both groups.

\section{RESULTS}

Tabel 1 showed the mean value of students family had focused care competencies before experiment were not differently significant. Advance test by using Mann Whitney test result showed $\mathrm{p}=0,994$. Meanwhile, the mean value of students focused care after experiment were differently significant. Advance test by using Mann Whitney test result showed $\mathrm{p}=0,000$.

\section{DISCUSSION}

Family nursing is one of the important aspects of nursing professional platform. A

Table1. Distribution of respondents based on the effect of classroom simulation learning method in nursing student's family focused care competencies in STIKES Maranatha Kupang 2016 (n $=34$ )

\begin{tabular}{llccccc}
\hline $\begin{array}{c}\text { Nursing Student's Family } \\
\text { Focused care Competencies }\end{array}$ & $\begin{array}{c}\text { Group of } \\
\text { respondent }\end{array}$ & Mean & SD $^{*}$ & Median & $\begin{array}{c}\text { Min- } \\
\text { Maks }\end{array}$ & p \\
\hline \multirow{2}{*}{ Pre } & Experimental & 19,24 & 18 & 4,18 & $13-24$ & \multirow{2}{*}{0,944} \\
\multirow{2}{*}{ Post } & Control & 19,29 & 19 & 3,39 & $13-24$ & \\
& Experimental & 27,53 & 28 & 2,29 & $22-30$ & \multirow{2}{*}{0,000} \\
\hline
\end{tabular}

*SD: Standard Deviation 
nurse is required to be able to have the ability to establish a positive collaborative relationship between the nurse and family. Nursing education is required to have a commitment to the development of family nursing education in an effort to highlight the significance of nursing care benefits to health and well-being of individuals in the family, and family as a whole.

According to Denham (2016), that the process of education and research in family nursing is considered remain insufficient. This is due to the lack of scientific core integration into the family focused nursing education, and education focus is still on the mechanisms of biomedical and communications. Meanwhile, family care requires a different pedagogical approach to teach the appropriate domains that essence in family-focused care to the students. Family-focused care actions will lead to a broader understanding and regard the family as a unit system in the fulfillment of their needs. So the family-focused care measures will be effective and efficient when nurses have a good competence in providing nursing care.

Competence can be defined as the ability to perform specific tasks in a certain way to achieve the expected results. In this context, in carrying out their duties, a person must have the ability to apply knowledge, skills both in completing the tasks new or unusual executed in accordance with established procedures (Lane, D.S. and VSR, 1998). In nursing care, competence is defined as a person's ability to integrate knowledge, attitudes, and skills shown in performance when providing nursing care. Thus, the quality of services provided by nurses depends on its competence.

In fact, some studies indicate that the current competence of nurses still are in the poor category. The survey results of the World Health Organization (WHO) in collaboration with the Ministry of Health in 2011-2012 reflect only about $15 \%$ of nurses who graduate competence in accordance with the needs of today's job (Pardede, 2013). It required an effort to solve these problems, one of them by developing a learning system of nursing practice, which brings real environment in families into educational settings through the simulation of clinical practice in the classroom.

Clinical practice is an important part of the nursing education process which aims to implement the learning process in the classroom and laboratory practice to a clinical situation that describes the real conditions directly related to the patient (Firoozehchian, Ezbarmi, \& Dadgaran, 2012). In the curriculum of nursing diploma, they have a clinical practice study load greater than the classroom study that $60 \%$ of the total credits available. Thus, the quality of learning by doing will determine the quality of graduates produced. Practice learning system that had been running still reap many problems and focused on achieving the target of student acquired without any evaluation of the quality of practice learning itself.

Results of preliminary studies (unpublished) carried out by researchers and teams of the 91 lecturers from 25 provinces in Indonesia, as many as $58.2 \%$ stated not satisfied with the clinical practice system that runs Additionally, this data is supported by an idea of competence early in this research which indicates problems in the quality of teaching practice in nursing education.

The quality of clinical practice learning is influenced by several interrelated components. Jette et al. (2014) to formulate some elements that can be used as a basis for assessing the quality of learning by using Donabedian conceptual framework includes structural components, processes, and outcomes. Structural components consist of, regulation practices, cost planning, activity planning of clinical practice that includes training precept/clinical supervisor and learning model that will be used. The process consists of cooperation institutions and field of practices, student placement, monitoring, implementation and evaluation of the learning model; and the yield components consist of student competence achievement, satisfaction and cost effectiveness (Jette, Nelson, \& Palaima, 2014). Aspects that are the focus of 
this research is a form of simulated learning methods in the classroom to the family nursing student competence.

According to Maris and Scallan (2012), the simulation is an effective learning method for teaching. Development of the use of simulation as a teaching method developed rapidly, but the use of simulation focuses on clinical teaching. Learning by simulation strategy provides several benefits to, especially in facilitating students to gain effective feedback, repeated teaching of the tasks that have been studied, estimating the difficulties and obstacles encountered during providing care, variations in the case, controlling the individual teaching and learning environment.

The results of this study indicate that there are significant simulation learning methods in the classroom to the student competence in family-focused care with $p=0.000$. This is according to research conducted by Oermann and Gaberson (2014), simulations in the world able to accommodate the family nursing teaching focus in achieving psychomotor abilities, caring and family nursing process. Learning through simulations in the classroom had benefits in a limited practice space utilization preparation of students' ability to home skills-essential skills and experience of critical thinking. Simulations can also be useful to increase the confidence of students, improve communication skills and competencies that can be prepared to deal with a family in real life simulation (Shea \& Miners, 2013; Rutherford \& Hemming, 2012; \& Rafeldt, 2013). Simulation perceived by educators as a valuable method and very helpful when teaching the basic capabilities of nursing and specific capabilities such as care-focused family on the student, but it is also an effective opportunity for educators to evaluate students through the assessment of performance capability in the face of the actual situation (Redden 2015).

The use of simulation in the classroom will be a major factor in building self-belief of the student while in the real environment in the family (Weaver, 2012). According to the Directorate of Student Learning and Higher
Education (2014), that simulation is a model that brings a situation similar to the real into the classroom. So, we need a guide (tools) that is able to accommodate the educator / teacher of nursing in providing simulation learning methods in the classroom in order to raise the competence of students to be prepared to provide nursing care for a real family. One instrument that is considered important by the researchers to be able to guide the important items in family nursing is nursing instrument Van Gelderen family.

According to Van Gelderen, Krumwiede, $\&$ Christian (2016), that the use of evaluation instruments is also an important thing in order to provide convenience in providing consistent feedback and develop skills that are essential in the family nursing students. Educators with clear evaluation instruments will maximize the use of learning methods with simulations in the nursing family. Evaluation instrument that can be used of Van Galderen sections that include important elements such as factor family communication and family care factors as clients. The section will provide comprehensive compliance capabilities of the ability of students during the process of learning through simulation.

\section{CONCLUSION}

The application of simulation learning method significantly influences increase student competence in family-focused care. This is strong evidence that the simulation is one method of learning that needs to be done by the lecturer in family nursing practice learning.

Teacher of nursing in order to implement a simulation which is one method of learning in the classroom as a strategy to improve the quality of teaching and learning in the classroom before the clinical practice in the nursing focused family. Evaluation of family nursing exam may use the rubric Van Gelderen. Education and research in nursing can make the results of this study as one of the innovations to increase student competence in conducting family focused care. Further studies on clinical practice teaching methods 
with better preparation, such as training and socialization precept of learning models to the lecturers and students to the maximum so that the implementation of this practice learning methods implemented comprehensively.

\section{REFERENCE}

Denham, S. A. (2016). Moving to family-focused care. In Denham, S. A., Eggenberger, P., Young, P., \& Krumwiede, N. (Eds.), Family-focused nursing care. Philadelphia, PA: F.A. Davis. (pp. 116).

Direktorat Pembelajaran dan Kemahasiswaan DIKTI. (2014). Buku kurikulum pendidikan tinggi. Jakarta: DIKTI

Eggenberger, Sandra \& Regan, Mary (2012), Expanding Simulation to Teach Family Nursing. Journal of Nursing Education. SLACK Incorporated.

Firoozehchian F, Ezbarmi ZT, Dadgaran I. Nursing-Midwifery Students and Teachers' Views of Effective Factors in Clinical Education. Procedia - Soc Behav Sci [Internet]. Elsevier B.V.; 2012 [cited 2016 Aug 13];47:1832-7. Available from: http://linkinghub.elsevier.com/ retrieve/pii/S1877042812026444

Gaberson, Kathleen \& Oermann, Marylin (2014), Clinical Teaching Streategies in Nursing. New York. Springer Publishing Company.

Jette DU, Nelson L, Palaima M, Wetherbee E. How Do We Improve Quality in Clinical Education? Examination of Structures, Processes, and Outcomes. J Phys Theraapy Educ. 2014;28.
Lane, D.S. and VSR. Defining competencies and performance indicators for physicians in medical management. $\mathrm{Am}$ J Prev Med. 1998;14:229-36.

Maris, J., \& Scallan, S (2012). High Fidelity Trainee Simulation to Improve Trainee Performances. The Clinical Teacher. Blackwell Publishing.

Oermann, Marylin \&Gaberson, Kathleen. (2014). Evaluation and Testing In Nursing Education. New York. Springer Publishing Company.

Pardede D. Survey Kualitas Pendidikan Keperawatan \& Kebidanan di Indonesia (WHO) Tahun 2011-2012. Batam; 2013.

Van Gelderen, S., Krumwiede, N., \& Christian, A. (2016). Teaching family nursing through simulation: family-care rubric development. Clinical Simulation in Nursing, 12(5), 159-170. http://dx.doi. org/10.1016/j.ecns.2016.01.002

Zavertnik, J. E., Huff, T. A., \& Munro, C. L. (2011). Conversations in end- of-life care: Communication tools for critical care practitioners. Nursing in Critical Care, 16(3), 124-130.

Zavertnik, Jean, Huff, Tanya, \& Munro, Cindy (2012). Innovative Approach to Teaching Communication Skills to Nursing Student. Journal Nursing Education. SLACK Incorporated. 